Małgorzata Podogrodzka

\title{
NIESTABILNOŚĆ ZATRUDNIENIA A ZACHOWANIA MATRYMONIALNE NA OBSZARACH MIEJSKICH I WIEJSKICH W POLSCE W OSTATNIEJ DEKADZIE
}

\section{Uwagi wstępne}

Obserwowane od początku lat 90. zmiany procesu zawierania małżeństw, polegające na spadku jego natężenia oraz przesunięciu decyzji o zawarciu związku małżeńskiego do starszych grup wieku, znajdują się w centrum zainteresowania wielu badaczy. Dodatkowo, proces ten odmiennie przebiega na obszarach miejskich i wiejskich. Wśród głównych determinant je kształtujących wymienia się m.in. nowe warunki uczestnictwa na rynku pracy. Wzrost wymagań tego rynku, rosnące znaczenie wykształcenia dla osiągnięcia odpowiedniej na nim pozycji oraz zagrożenie bezrobociem powodują konieczność zwiększenia wysiłków w celu jej pozyskania oraz utrzymania. Z czasem wyraźnie maleje pewność i stabilność zatrudnienia. W konsekwencji decyzje o zawarciu małżeństwa mogą być odroczone do starszych grup wieku' ${ }^{1}$.

Postrzeżenia te potwierdzają ekonomiczne teorie małżeńskości. Przyjmując założenie o racjonalności postępowania człowieka, wynikającej z kalkulacji ekonomicznej oraz traktowania małżeństwa jako swoistego dobra konsumpcyjnego, w koncepcji zaproponowanej przez G.S. Beckera zawarcie związku małżeńskiego nastąpi wtedy, gdy partnerzy dostrzegą korzyści płynące z wymiany dóbr i usług między nimi². W teorii zaproponowanej przez R.A. Easterlina zachowanie jednostki na rynku matrymonialnym ukształtowane jest głównie przez doświadczenia wyniesione z okresu dzieciństwa. Wysoka stopa życiowa osiągana we wczesnych latach życia wykształca takie same aspiracje co do przyszłości. Decyzję o zawarciu małżeństwa

\footnotetext{
1 Por. np. H. Domański, D. Przybysz, Bariery zawierania małżeństw w Polsce w latach 1977-2007, „Studia Socjologiczne" nr 1 (192), 2000; T. Barański, S. Kaczmarek, Changing marriage and divorce rate in Poland compared to other EU Countries, „Bulletin of Geography” („Socio-Economic Series”) Nr 7, 2007.

2 Por. np. G.S. Becker, Ekonomiczna teoria zachowań ludzkich, PWN, Warszawa 1990.
} 
warunkuje osiągany dochód przez partnerów, a skłonność ta wzrasta proporcjonalnie do wzrostu relatywnych dochodów partnerów³.

Opracowanie poświęcone jest analizie przestrzennego zróżnicowania małżeńskości oraz ustaleniu determinant rynku pracy (określających stabilność zatrudnienia) je kształtujących w Polsce w latach 1999-2010, prowadzonej odrębnie dla obszarów miejskich i wiejskich. Opis ten pozwoli na weryfikację następujących hipotez badawczych: w województwach charakteryzujących się złą sytuacją na rynku pracy, opisywaną przez zmienne bezrobocia, odnotowujemy spadek natężenia zawieranych małżeństw oraz odraczanie decyzji o zawarciu związku małżeńskiego do starszych grup wieku. W regionach, gdzie sytuacja na rynku pracy jest relatywnie lepsza, opisywana przez zmienne zatrudnienia, obserwujemy wzrost natężenia zawieranych małżeństw oraz nieodkładanie decyzji o zawarciu związku małżeńskiego do starszych grup wieku.

W literaturze przedmiotu trudno znaleźć opracowanie poświęcone tym zagadnieniom w ujęciu regionalnym. Dotyczą one wybranego punktu czasu oraz określonego niewielkiego obszaru.

W rozważaniach za badaną jednostkę (obiekt) przyjęliśmy województwo. Stanowi ona region administracyjny kraju, który charakteryzuje się wysokim stopniem instytucjonalizacji oraz jest podstawową jednostką strukturyzacji i organizacji przestrzennej Polski ${ }^{4}$.

Proces zawierania małżeństw opisany został za pomocą współczynnika zawierania małżeństw, który wyraża liczbę zawartych małżeństw na 1000 osób, oraz wzorca zawierania małżeństw opisanego za pomocą rozkładu cząstkowych współczynników zawierania małżeństw według pięcioletnich grup wieku z przedziału 15-59. Do opisu rynku pracy (stabilności zatrudnienia) ${ }^{5}$ wybrano następujące charakterystyki: dla opisu bezrobocia (zmienne te określają „złą" stronę rynku pracy) ${ }^{6}$ : stopę bezrobocia, wskaźnik stabilności bezrobocia, tj. relację napływu do odpływu osób wchodzących w skład tej populacji, średni wiek osób bezrobotnych, odsetek bezrobotnych z wykształceniem co najwyżej zasadniczym zawodowym, odsetek osób przebywających w tej populacji powyżej dwanaście miesięcy; dla opisu zatrudnienia

3 Za B. Radzikowska, Płodność w Polsce w kontekście drugiego przejścia demograficznego. Modelowanie i prognozowanie, Wydawnictwo AE, Wrocław1995; J.Z. Holzer, Demografia, PWE, Warszawa 1999.

4 Por. Z. Chojnicki, Region w ujęciu geograficzno-systemowym, w: Podstawy regionalizacji geograficz$n e j$, red. T. Czyż, Bogucki, Wydawnictwo Naukowe, Poznań 1996, s. 7-43.

${ }_{5}^{5}$ Wybór zmiennych opisujących rynek pracy dokonany został po ich wcześniejszej statystycznej weryfikacji, tj. określeniu zmienności wartości w czasie oraz skorelowaniu z innymi zmiennymi.

6 Zmienne opisujące bezrobocie ukazują natężenie tego zjawiska oraz jakościową stronę zasobu bezrobotnych. 
(zmienne te określają „dobrą" stronę rynku pracy): wskaźnik zatrudnienia, odsetek osób zatrudnionych w sektorze publicznym, wskaźnik stabilności zatrudnienia, tj. relację między osobami podejmującymi a ją tracącymi. Zakładamy, że każda $\mathrm{z}$ tych zmiennych $\mathrm{w}$ jednakowy sposób determinuje przestrzenne zmiany małżeńskości oraz że charakterystyki należące do grupy pierwszej są destymulantami dla zmian małżeńskości, a z grupy drugiej - jej stymulantami. Wzrost zagrożenia bezrobociem może ograniczać decyzje o zawarciu związku małżeńskiego, natomiast stabilne zatrudnienie może im sprzyjać.

Do opisu zmian w czasie przestrzennego zróżnicowania małżeńskości wykorzystano podstawowe miary rozproszenia, tj. rozstęp oraz współczynnik zmienności, a do określenia stabilności rozkładów według województw - współczynnik korelacji liniowej. Przyjmujemy, że o ich stabilności mówimy wtedy, gdy miara zależności (współczynnik korelacji) przyjmuje wartości wyższe niż $0,475^{8}$. Ocenę stopnia zaawansowania zmian wzorca małżeńskości (rozkładu cząstkowych współczynników małżeńskości według wieku) przeprowadzono przez porównanie rzeczywistych rozkładów cząstkowych współczynników małżeńskości według wieku ze wzorcem hipotetycznym, tj.

$W_{25-29}=100>W_{30-34}=90>W_{20-24}=80>w_{35-39}=50>w_{40-44}=30>w_{45-49}=10$

Wykorzystując miarę podobieństwa struktur, ustalono odległości między nimi, co pozwoliło określić, na ile rozkłady te są jednorodne oraz jak dalece różnią się od wzorca hipotetycznego. W analizie wykorzystaliśmy następujący miernik podobieństwa struktur:

$$
P\left(Q_{i}, Q_{r}\right)=1-\frac{\sum_{j=1}^{m}\left|q_{i j}-q_{r j}\right|}{\sum_{j=1}^{m}\left|q_{i j}+q_{r j}\right|}
$$

gdzie $q_{i j}$ to rozkład rzeczywistych współczynników małżeńskości według wieku, $q_{r j}$ to rozkład hipotetycznych współczynników małżeńskości według wieku. Im wyższe są wartości tej miary, tym mniejsze podobieństwo między rozkładami ${ }^{9}$.

7 Zmienne opisujące zatrudnienie ukazują natężenie tego zjawiska oraz jakościową stronę zasobu pracujących.

8 Przy poziomie istotności 0,05 hipotezę zerową mówiącą o braku zależności między dwoma rozkładami należy odrzucić na korzyść hipotezy alternatywnej.

9 Por. np. A. Młodak, Analiza taksonomiczna w statystyce regionalnej, Difin, Warszawa 2006. 
Do klasyfikacji regionów podobnych ze względu na natężenie małżeńskości oraz podobieństwa wzorca małżeńskości wykorzystano jedną z metod taksonomicznych, która oparta jest na syntetycznym mierniku rozwoju. Służy ona do liniowego uporządkowania obiektów ze względu na rozwój omawianego zjawiska ${ }^{10}$. Zbiór jednorodnych województw określono z relacji między średnią arytmetyczną a odchyleniem standardowym, tj.

$\bar{x} \pm k \cdot S(X)$

gdzie $k$ przyjmuje wartość 0,$0 ; 0,5$ oraz 1,0. Utworzono sześć jednorodnych grup województw.

W analizie wpływu wybranych charakterystyk rynku pracy na proces zawierania małżeństw wykorzystaliśmy wieloraką regresję liniową. Rozważania prowadzone są odrębnie dla przestrzennego zróżnicowania natężenia małżeńskości oraz wzorca małżeńskości według miejsca zamieszkania (miasto, wieś) oraz lat 1999 i 2010. Ocena istotności wpływu zmiennych rynku pracy na przestrzenne zróżnicowanie procesu zawierania małżeństw przeprowadzona zostanie przy poziomie istotności 0,05.

Informacje statystyczne wykorzystane w opracowaniu pochodzą z Roczników Demograficznych, Roczników Statystycznych Województw oraz Roczników Statystycznych Pracy z różnych lat okresu 2000-2010. Dostępność danych wyznacza zakres prowadzonych analiz.

\section{Przestrzenne zróżnicowanie współczynnika zawierania małżeństw}

W ostatniej dekadzie w ujęciu ogólnopolskim skłonność do zawierania małżeństw podlegała nielicznym, ale wyraźnym wahaniom w czasie. Przez pierwsze pięć lat wartość współczynnika zawierania małżeństw nieznacznie malała, przez kolejne cztery rosła, ale pod jego koniec znowu malała. Zmiany te przebiegały podobnie wśród osób zamieszkałych na obszarach miejskich i wiejskich, ale nadal w mieście natężenie to jest niższe aniżeli na wsi.

\footnotetext{
10 Klasyfikacja zbioru obiektów podobnych sprowadza się do podziału obiektów według jednej zmiennej. Punktem wyjścia w tej metodzie jest uporządkowanie obiektów według nierosnących (niemalejących) wartości syntetycznego miernika, a następnie podział analizowanego zbioru na cztery (lub więcej) grupy przy wykorzystaniu relacji między średnią arytmetyczną a odchyleniem standardowym.
} 
Syntetyczne miary rozproszenia wskazują ${ }^{11}$ na przestrzenne ujednolicanie się wartości współczynnika małżeństw oraz na rosnącą koncentrację województw wokół wartości przeciętnej, zarówno na obszarach miejskich, jak i wiejskich. Jednocześnie przekształcenia te były nieco intensywniejsze i bardziej zróżnicowane na wsi i nie zawsze przebiegały $\mathrm{w}$ tym samym kierunku co $\mathrm{w}$ miastach. $\mathrm{Z}$ czasem zmniejszyły się nieco przestrzenne różnice $\mathrm{w}$ natężeniu tej miary według miejsca zamieszkania. Mimo tych przekształceń relacje między województwami nie uległy zasadniczej konwersji.

W badanym okresie województwa odznaczające się podobnym poziomem wartości współczynnika małżeńskości rozrzucone były po całym obszarze Polski. Trudno jest tym samym wyodrębnić zwarte przestrzennie regiony o podobnej skłonności. Większość obiektów położonych w części środkowej i środkowopołudniowej Polski charakteryzowała się najniższą skłonnością, natomiast w części środkowopółnocnej kraju - najwyższą. Miejsce zamieszkania nie było czynnikiem istotnie różnicującym ten obraz. Mimo że rozkład województw według wartości tej miary istotnie nie zmienił się w czasie, to natężenie i kierunek zmian nie były takie same we wszystkich obiektach. Z czasem skłonność do zawierania małżeństw wzrosła w części środkowej kraju, zwłaszcza na obszarach miejskich. Nadal jej spadek odnotowujemy na obszarach wiejskich w części środkowowschodniej i środkowopołudniowej Polski (por. rysunek 1).

Zmiany procesu zawierania małżeństw można bliżej ocenić na podstawie cząstkowych współczynników małżeńskości według wieku. Wskazują one, iż w latach 1999-2010 w ujęciu ogólnopolskim nastąpiło znaczące obniżenie się natężenia małżeńskości w grupie wieku 20-24 lat, natomiast wzrost w wieku 30-34 lata. Te nierównomierne zmiany sprawiły, że rozkład cząstkowych współczynników małżeńskości według wieku uległ zmianie w czasie. Krzywa ta nieco bardziej spłaszczyła się, dominanta rozkładu przesunęła się do starszych grup wieku i dodatkowo zmianie uległy relacje między niektórymi cząstkowymi współczynnikami, niezależnie od miejsca zamieszkania.

Przesunięcie mody rozkładu do starszych grup wieku wynika z dwóch przesłanek. Po pierwsze, z odroczenia decyzji o zawarciu pierwszego związku małżeńskiego do starszych grup wieku lub ze zwiększonego natężenia małżeństw powtórnych. Ponieważ analiza natężenia małżeństw powtórnie zawieranych nie wykazuje istotnych zmian w czasie, możemy założyć, iż to pierwszy z wymienionych czynników zadecydował o jej przesunięciu.

11 W roku 1999 współczynnik zmienności małżeńskości na obszarach miejskich wynosił 4,6\%, a dekadę później 4,3\%. Na obszarach wiejskich wartości tej miary wynosiły odpowiedni 8,4\% i 6,6\%. 


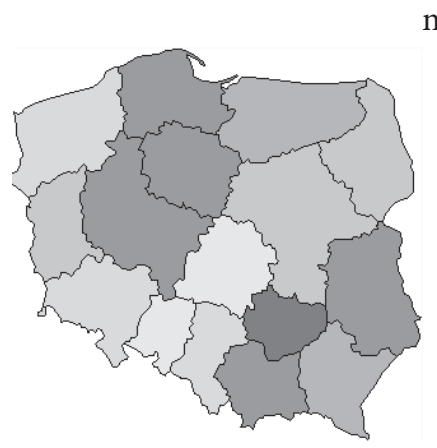

miasto
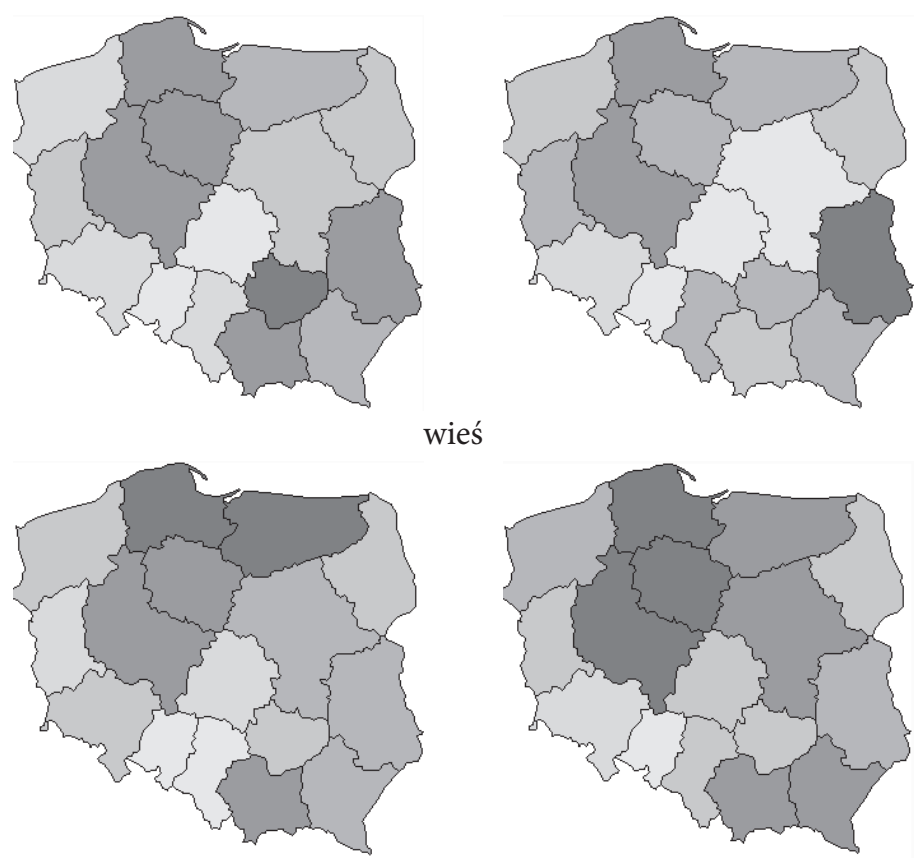

1233456

wieś

Uwaga: Im ciemniejszy kolor (im wyższy nr grupy), tym wyższe wartości współczynnika małżeńskości. Źródło: Opracowanie własne na podstawie danych z Rocznika Demograficznego 2000 i 2010, GUS, Warszawa.

W ujęciu przestrzennym odnotowujemy również istotne przekształcenia w natężeniu cząstkowych współczynników zawierania małżeństw według wieku, które przebiegały $\mathrm{z}$ różną intensywnością według województw. Z czasem wzorzec małżeńskości stał się jeszcze bardziej zróżnicowany regionalnie, a zmiany te odmiennie kształtowały się według miejsca zamieszkania. Na obszarach miejskich wzrost dyspersji natężenia małżeńskości obserwujemy we wszystkich grupach wieku, przy jednoczesnym wzroście rozproszenia wokół wartości ogólnopolskiej w młodszych grupach wieku i jej spadku w grupach starszych. Na obszarach wiejskich zaś rośnie przestrzenne zróżnicowanie tej miary praktycznie dla wszystkich grup wieku, spada natomiast w stosunku do średniej, i to jedynie w grupie wieku 25-34. Świadczy to o rosnącym $\mathrm{w}$ czasie przestrzennym zróżnicowaniu w wartościach cząstkowych współczynników małżeńskości, które w różnym stopniu wpłynęły na zmiany współczynnika małżeńskości ogółem. W konsekwencji wyodrębniły się różne przestrzenne 
wzorce małżeńskości według miejsca zamieszkania, a tym samym i różny ich stopień przekształceń.

W badanym okresie na obszarach wiejskich przestrzenne zmiany wzorca małżeńskości były nieco bardziej jednorodne, tj. większa liczba województw charakteryzowała się podobnym poziomem wartości miary podobieństwa aniżeli na obszarach miejskich. Jednocześnie województwa charakteryzujące się zbliżonym wzorcem małżeńskości rozrzucone były w różnych części kraju, nie tworząc tym samym zwartych przestrzennie obszarów, niezależnie od miejsca zamieszkania.

\section{Rysunek 2. Rozkład województw według miary podobieństwa wzorca małżeńskości} i miejsca zamieszkania w latach 1999 i 2010

1999
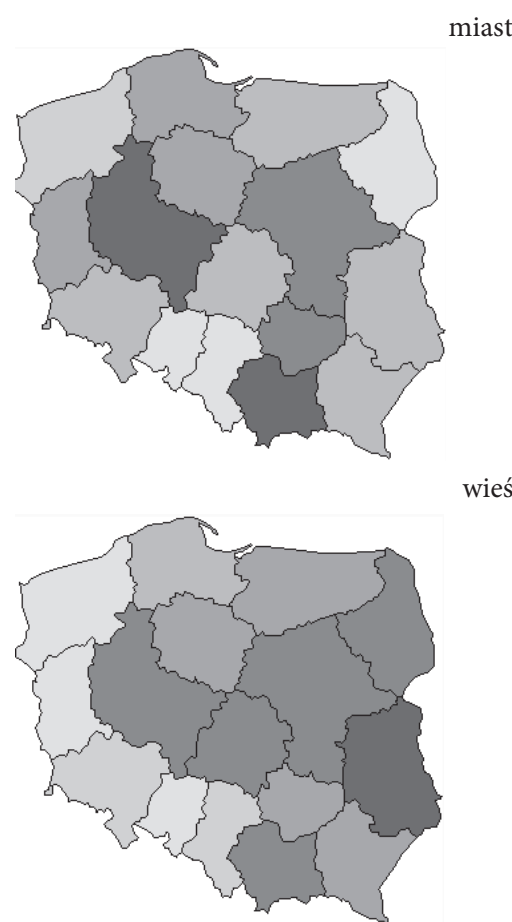

2010

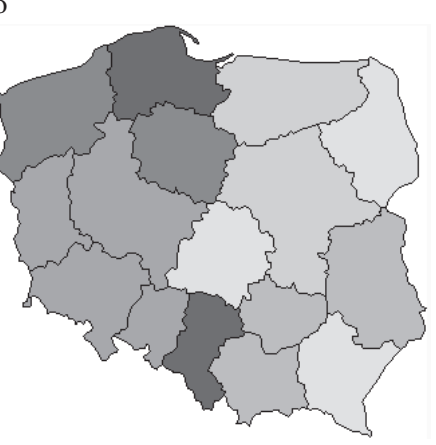

wieś

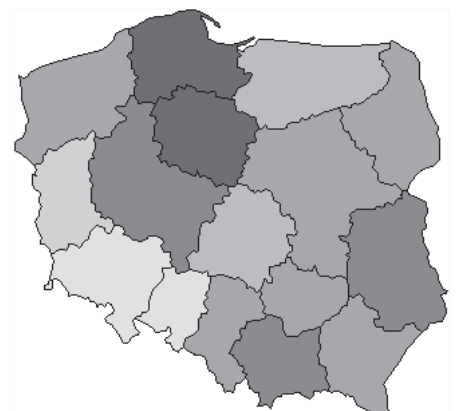

Uwaga: Im ciemniejszy kolor (im wyższy nr grupy), tym bardziej zaawansowany wzorzec małżeńskości. Źródło: Opracowanie własne na podstawie danych z Rocznika Demograficznego 2010, GUS, Warszawa. 


\section{Proces zawierania małżeństw a rynek pracy}

W analizie wpływu zmiennych rynku pracy (zmienne objaśniające) na przestrzenne zróżnicowanie natężenia małżeńskości oraz na stopień przekształceń wzorca małżeńskości (zmienne objaśniane) wykorzystaliśmy liniowy model regresji wielorakiej postaci:

$Y=\beta_{1} \cdot \chi_{1}+\beta_{2} \cdot \chi_{2}+\ldots+\beta_{n^{-1}} \cdot \chi_{i-1}+\beta_{n} \cdot \chi_{i}+\beta_{0}+\varepsilon$

gdzie $\beta_{i}$ to parametry modelu opisujące wpływ „netto” i-tej zmiennej niezależnej na zmienną niezależną, a $\varepsilon$ to składnik losowy ${ }^{12}$. Stosowanie tej metody wymaga, aby żadna ze zmiennych niezależnych nie była kombinacją liniową innych zmiennych niezależnych (brak współliniowości). Przyjmując tolerancję na poziomie 0,1, możemy stwierdzić, że żadna z proponowanych charakterystyk nie stanowi takiej kombinacji (tabela 1).

Tabela 1. Statystyki współliniowości (współczynniki tolerancji) dla zmiennych niezależnych opisujących bezrobocie oraz zatrudnienie w liniowym modelu regresji wielorakiej dla wojewódzkiego współczynnika małżeńskości oraz wzorca małżeńskości w latach 1999 i 2010

\begin{tabular}{|c|c|c|c|c|c|c|c|c|}
\hline \multirow{5}{*}{ Zmienne niezależne } & \multicolumn{8}{|c|}{ Statystyka współliniowości (tolerancja) } \\
\hline & \multicolumn{2}{|c|}{$\begin{array}{l}\text { współczynnik } \\
\text { małżeńskości }\end{array}$} & \multicolumn{2}{|c|}{$\begin{array}{c}\text { wzorzec } \\
\text { matżeńskości }\end{array}$} & \multicolumn{2}{|c|}{$\begin{array}{l}\text { współczynnik } \\
\text { małżeńskości }\end{array}$} & \multicolumn{2}{|c|}{$\begin{array}{c}\text { wzorzec } \\
\text { małżeńskości }\end{array}$} \\
\hline & 1999 & 2010 & 1999 & 2010 & 1999 & 2010 & 1999 & 2010 \\
\hline & \multicolumn{4}{|c|}{ miasto } & \multicolumn{4}{|c|}{ wieś } \\
\hline & \multicolumn{8}{|c|}{ bezrobocie } \\
\hline Stopa bezrobocia & 0,671 & 0,825 & 0,661 & 0,825 & 0,671 & 0,825 & 0,671 & 0,825 \\
\hline Wskaźnik stabilności bezrobocia & 0,172 & 0,204 & 0,171 & 0,204 & 0,172 & 0,204 & 0,172 & 0,204 \\
\hline Średni wiek bezrobotnych & 0,284 & 0,616 & 0,273 & 0,616 & 0,284 & 0,616 & 0,284 & 0,616 \\
\hline $\begin{array}{l}\text { Udział bezrobotnych z wykształceniem } \\
\text { poniżej zasadniczego }\end{array}$ & 0,410 & 0,620 & 0,410 & 0,620 & 0,410 & 0,620 & 0,410 & 0,620 \\
\hline $\begin{array}{l}\text { Odsetek bezrobotnych przebywających } \\
\text { w tej populacji powyżej } 12 \text { miesięcy }\end{array}$ & 0,202 & 0,161 & 0,201 & 0,161 & 0,202 & 0,161 & 0,202 & 0,161 \\
\hline & \multicolumn{8}{|c|}{ zatrudnienie } \\
\hline Wskaźnik zatrudnienia & 0,475 & 0,784 & 0,475 & 0,784 & 0,475 & 0,784 & 0,475 & 0,784 \\
\hline $\begin{array}{l}\text { Odsetek osób zatrudnionych } \\
\text { w sektorze publicznym }\end{array}$ & 0,818 & 0,775 & 0,618 & 0,775 & 0,618 & 0,775 & 0,618 & 0,775 \\
\hline Wskaźnik stabilności zatrudnienia & 0,678 & 0,984 & 0,678 & 0,984 & 0,678 & 0,984 & 0,678 & 0,984 \\
\hline
\end{tabular}

Źródło: Opracowanie własne z wykorzystaniem pakietu komputerowego SPSS.

12 Por. G.S. Maddala, Ekonometria, Wydawnictwo Naukowe PWN, Warszawa 2006; A. Stanisz, Przystępny kurs statystyki z zastosowaniem STATISTICA PL na przykładach z medycyny, StatSoft, Kraków 2006. 
Istotne skorelowanie zmiennej zależnej ze zmiennymi niezależnymi, a tym samym wysoki stopień wyjaśnienia zmienności zmiennej objaśnianej otrzymaliśmy dla wszystkich charakterystyk rynku pracy. Nieco lepsze dopasowanie tej funkcji teoretycznej do danych empirycznych otrzymaliśmy dla zmiennych bezrobocia, zwłaszcza na obszarach miejskich. Natomiast dla cech zatrudnienia nieco wyższe dopasowanie dotyczyło obszarów wiejskich. Również zmienne rynku pracy w nieco wyższym stopniu wyjaśniały stopień przekształceń wzorca małżeńskości, tj. odkładanie decyzji o zawarciu związku do starszych grup wieku, aniżeli jego natężenie, niezależnie od miejsca zamieszkania. Niezależnie zaś od charakterystyk opisujących proces zawierania małżeństw wpływ zmiennych rynku pracy na ich przekształcenia (natężenie) maleje z czasem, zwłaszcza na obszarach wiejskich. Można zatem przypuszczać, że różny stopień zagrożenia bezrobociem oraz stabilność zatrudnienia miały większy wpływ na przestrzenne zróżnicowanie decyzji matrymonialnych na początku badanego okresu aniżeli dekadę później, zwłaszcza dla osób zamieszkałych na obszarach miejskich (tabela 2).

Tabela 2. Miary dopasowania danych empirycznych do modelu liniowej funkcji regresji współczynnika małżeńskości oraz wzorca małżeńskości opisywanej przez zmienne bezrobocia i zatrudnienia w latach 1999 i 2010

\begin{tabular}{|c|c|c|c|c|c|c|}
\hline \multirow{4}{*}{ Rok } & $\begin{array}{c}\text { Współczynnik } \\
\text { korelacji } \\
\text { wielorakiej }\end{array}$ & $\begin{array}{c}\text { Współczynnik } \\
\text { determinacji }\end{array}$ & $\begin{array}{c}\text { Standardowy } \\
\text { błąd } \\
\text { oszacowania }\end{array}$ & $\begin{array}{c}\text { Współczynnik } \\
\text { korelacji } \\
\text { wielorakiej }\end{array}$ & $\begin{array}{l}\text { Współczynnik } \\
\text { determinacji }\end{array}$ & $\begin{array}{c}\text { Standardowy } \\
\text { błąd } \\
\text { oszacowania }\end{array}$ \\
\hline & \multicolumn{3}{|c|}{ współczynnik małżeńskości } & \multicolumn{3}{|c|}{ wzorzec małżeńskości } \\
\hline & \multicolumn{6}{|c|}{ zmienne bezrobocia } \\
\hline & \multicolumn{6}{|c|}{ miasto } \\
\hline 1999 & 0,780 & 0,608 & 0,235 & 0,794 & 0,630 & 0,022 \\
\hline \multirow[t]{2}{*}{2010} & 0,770 & 0,593 & 0,221 & 0,777 & 0,604 & 0,014 \\
\hline & \multicolumn{6}{|c|}{ wieś } \\
\hline 1999 & 0,667 & 0,445 & 0,5452 & 0,816 & 0,665 & 0,030 \\
\hline \multirow[t]{3}{*}{2010} & 0,600 & 0,360 & 0,4036 & 0,642 & 0,412 & 0,023 \\
\hline & \multicolumn{6}{|c|}{ zmienne zatrudnienia } \\
\hline & \multicolumn{6}{|c|}{ miasto } \\
\hline 1999 & 0,627 & 0,393 & 0,2677 & 0,581 & 0,338 & 0,026 \\
\hline \multirow[t]{2}{*}{2010} & 0,494 & 0,244 & 0,3025 & 0,523 & 0,274 & 0,017 \\
\hline & \multicolumn{6}{|c|}{ wieś } \\
\hline 1999 & 0,607 & 0,369 & 0,5304 & 0,708 & 0,501 & 0,034 \\
\hline 2010 & 0,512 & 0,262 & 0,3957 & 0,499 & 0,249 & 0,024 \\
\hline
\end{tabular}

Źródło: Opracowanie własne z wykorzystaniem pakietu komputerowego SPSS.

W tabelach 3 i 4 przedstawiono wyniki oszacowania parametrów wojewódzkiej funkcji regresji liniowej dla współczynnika małżeńskości oraz jego wzorca, 
a w tabelach 5 i 6 miary korelacji cząstkowej, które pozwalają na ocenę siły wpływu każdej ze zmiennych niezależnych osobno na zmienną zależną. Z informacji tych wynika, że w zależności od charakterystyki opisującej regionalne zróżnicowanie małżeńskości wpływ czynników je determinujących był nieco odmienny co do kierunku i siły oddziaływania. Zależał również od okresu badania i miejsca zamieszkania nowożeńców.

W roku 1999 na przestrzenne zróżnicowanie natężenia współczynnika małżeńskości na obszarach miejskich istotny wpływ miały wskaźnik stabilności bezrobocia oraz poziom wykształcenia osób bezrobotnych. Im wyższe wartości pierwszej z wyróżnionych miar, tj. napływ do bezrobocia przewyższał jego odpływ, tym niższe wartości współczynnika małżeńskości oraz mniej zaawansowany stopień przekształceń wzorca małżeńskości. Natomiast im wyższy udział bezrobotnych z wykształceniem zasadniczym zawodowym i poniżej, tym wyższa skłonność do zawarcia związku małżeńskiego i wyraźniejsze przekształcenia rozkładu cząstkowych współczynników małżeńskości według wieku. Oznacza to, że w województwach, w których odnotowaliśmy względnie większe prawdopodobieństwo zostania osobą bezrobotną w stosunku do pozostałych jednostek, malały szanse zawarcia związku małżeńskiego, a decyzje o jego zawarciu odkładane były przez nowożeńców do starszych grup wieku. Rosły one natomiast, jeżeli osoba bezrobotna charakteryzowała się niskim poziomem wykształcenia, ale związek ten zawierany był również przez osoby nieco starsze. Dekadę później czynniki te nie odgrywały już tak istotnej roli w ocenie przestrzennego zróżnicowania małżeńskości. Znaczenie miał zaś wiek osób bezrobotnych oraz czas ich przebywania w tej zbiorowości. Im niższe wartości tych charakterystyk, tym wyższe regionalne współczynniki małżeńskości oraz niższy stopień przekształceń wzorca małżeńskości. A zatem, im młodsza była osoba bezrobotna lub jej czas przebywania w tej populacji był dłuższy niż dwanaście miesięcy, tym wyższa była jej skłonność do zawarcia związku małżeńskiego.

Z czasem zmieniły się charakterystyki bezrobocia wpływające na przestrzenne zróżnicowanie małżeńskości na obszarach miejskich, ale w województwach odznaczających się relatywnie niskim jakościowo zasobem bezrobotnych w początkowym okresie odnotowujemy wysoką skłonność do zawarcia związku małżeńskiego, natomiast pod jego koniec czynnik ten nie miał już znaczenia. Ponadto odkładanie decyzji o zawarciu małżeństwa do starszych grup wieku nowożeńców dotyczyło przede wszystkim osób o wyższym niż przeciętny kapitale ludzkim. Można również sądzić, że z czasem sytuacja na regionalnych rynkach pracy przestała mieć wpływ na przestrzenne zróżnicowanie natężenia zawieranych małżeństw. 
Tabela 3. Parametry liniowej regresji wielorakiej współczynnika małżeńskości oraz wzorca małżeńskości opisanej przez zmienne bezrobocia według miejsca zamieszkania w latach 1999 i 2010

\begin{tabular}{|c|c|c|c|c|}
\hline \multirow{4}{*}{ Zmienne niezależne } & \multicolumn{4}{|c|}{$\begin{array}{c}\text { Współczynniki niestandaryzowane } \\
\text { [błąd standardowy] }\end{array}$} \\
\hline & \multicolumn{2}{|c|}{ współczynnik małżeńskości } & \multicolumn{2}{|c|}{ wzorzec małżeńskości } \\
\hline & 1999 & 2010 & 1999 & 2010 \\
\hline & \multicolumn{4}{|c|}{ miasto } \\
\hline Stopa bezrobocia & $+0,020[0,022]$ & $+0,025[0,020]$ & $-0,001[0,002]$ & $-0,001[0,001]$ \\
\hline $\begin{array}{l}\text { Wskaźnik stabilności } \\
\text { bezrobocia }\end{array}$ & $-0,176[0,170]$ & $+0,013[0,073]$ & $-0,027[0,016]$ & $-0,003[0,005]$ \\
\hline Średni wiek bezrobotnych & $-0,066[0,107]$ & $-0,212[0,064]$ & $+0,012[0,010]$ & $-0,001[0,004]$ \\
\hline $\begin{array}{l}\text { Udział bezrobotnych } \\
\text { z wykształceniem } \\
\text { poniżej zasadniczego }\end{array}$ & $+0,056[0,036]$ & $-0,010[0,034]$ & $+0,011[0,003]$ & $+0,002[0,002]$ \\
\hline \multirow[t]{2}{*}{$\begin{array}{l}\text { Odsetek bezrobotnych } \\
\text { przebywających } \\
\text { w tej populacji } \\
\text { powyżej } 12 \text { miesięcy }\end{array}$} & $-0,010[0,039]$ & $-0,028[0,033]$ & $-0,003[0,004]$ & $-0,004[0,002]$ \\
\hline & \multicolumn{4}{|c|}{ wieś } \\
\hline Stopa bezrobocia & $+0,023[0,050]$ & $-0,006[0,037]$ & $-0,004[0,003]$ & $+0,000[0,002]$ \\
\hline $\begin{array}{l}\text { Wskaźnik stabilności } \\
\text { bezrobocia }\end{array}$ & $-0,808[0,395]$ & $-0,099[0,133]$ & $-0,024[0,022]$ & $-0,009[0,008]$ \\
\hline Średni wiek bezrobotnych & $+0,151[0,248]$ & $-0,158[0,118]$ & $-0,010[0,014]$ & $-0,013[0,007]$ \\
\hline $\begin{array}{l}\text { Udział bezrobotnych } \\
\text { z wykształceniem } \\
\text { poniżej zasadniczego }\end{array}$ & $+0,122[0,083]$ & $+0,058[0,061]$ & $-0,003[0,005]$ & $-0,001[0,004]$ \\
\hline $\begin{array}{l}\text { Odsetek bezrobotnych } \\
\text { przebywających } \\
\text { w tej populacji } \\
\text { powyżej } 12 \text { miesięcy }\end{array}$ & $-0,111[0,089]$ & $-0,031[0,060]$ & $+0,003[0,005]$ & $-0,003[0,004]$ \\
\hline
\end{tabular}

Źródło: Opracowanie własne z wykorzystaniem pakietu komputerowego SPSS.

Na obszarach wiejskich sytuacja wyglądała nieco odmiennie od tej zaobserwowanej w miastach. W roku 1999 istotne znaczenie dla kształtowania się przestrzennych różnic w natężeniu współczynnika małżeńskości miał również poziom wykształcenia bezrobotnych, ale też i czas przebywania w populacji bezrobotnych. O ile dla pierwszej z wyróżnionych zmiennych odnotowujemy zależność dodatnią, o tyle dla drugiej ujemną. Im więcej bezrobotnych z wykształceniem co najwyżej zasadniczym zawodowym było zarejestrowanych w województwie, tym wyższa była w nim również skłonność do zawarcia związku małżeńskiego w stosunku do pozostałych jednostek. Natomiast im wyższy był udział bezrobotnych długookresowych, tym niższa była ta chęć. Charakterystyki te nie determinowały jednak przestrzennych zmian wzorca małżeńskości. W tym przypadku istotną cechą okazał się wskaźnik stabilności bezrobocia, tj. im wyższy napływ osób do bezrobocia niż jego 
odpływ, tym niższe przekształcenia rozkładu cząstkowych współczynników małżeńskości według wieku. Oznacza to, że w województwach charakteryzujących się niską jakością zasobów bezrobotnych odnotowujemy relatywnie wysokie współczynniki małżeńskości oraz niski stopień zaawansowania wzorca małżeńskości, tj. małżeństwa były zawierane przez stosunkowo młode osoby. Ponadto zagrożenie bezrobociem nie różnicowało przestrzennej skłonności do zawarcia związku małżeńskiego. Dziesięć lat później już nieco inne charakterystyki wpływały na przestrzenne zróżnicowanie małżeńskości, tj. wskaźnik stabilności zatrudnienia oraz wiek osób bezrobotnych. Wraz ze wzrostem wartości tych charakterystyk malały szanse zawarcia związku małżeńskiego, ale jeżeli był on już zawierany, to dotyczył głównie osób stosunkowo młodych.

Z czasem zmieniły się nieco charakterystyki wpływające na przestrzenne zróżnicowanie procesu zawierania małżeństw na obszarach wiejskich, ale podobnie jak na obszarach miejskich na początku badanego okresu niska jakość zasobu bezrobotnych przyczyniała się do wzrostu regionalnych wartości współczynnika małżeńskości, natomiast pod jego koniec już nie. Również ocena sytuacji na wojewódzkich rynkach pracy była istotna, ale im była ona gorsza, tym wyższe odnotowano współczynniki małżeńskości. Można zatem przypuszczać, że z czasem również na obszarach wiejskich wpływ zmiennych opisujących przestrzenne zróżnicowanie małżeńskości stracił nieco na znaczeniu.

Tabela 4. Siła zależności między zmiennymi wykorzystanymi w model liniowej regresji wielorakiej współczynnika małżeńskości oraz wzorca małżeńskości opisywanymi przez zmienne bezrobocia według miejsca zamieszkania w latach 1999 i 2010

\begin{tabular}{|c|c|c|c|c|c|c|c|c|}
\hline \multirow{4}{*}{ Zmienne niezależne } & \multicolumn{4}{|c|}{$\begin{array}{c}\text { Współczynniki standaryzowane } \\
\text { BETA }{ }^{\mathrm{a}}\end{array}$} & \multicolumn{4}{|c|}{$\begin{array}{c}\text { Współczynniki standaryzowane } \\
\text { BETA }^{\mathrm{a}}\end{array}$} \\
\hline & 1999 & 2010 & 1999 & 2010 & 1999 & 2010 & 1999 & 2010 \\
\hline & \multicolumn{2}{|c|}{ miasto } & \multicolumn{2}{|c|}{ wieś } & \multicolumn{2}{|c|}{ miasto } & \multicolumn{2}{|c|}{ wieś } \\
\hline & \multicolumn{4}{|c|}{ współczynnik małżeńskości } & \multicolumn{4}{|c|}{ wzorzec małżeńskości } \\
\hline Stopa bezrobocia & 0,222 & 0,273 & 0,131 & 0,045 & 0,082 & 0,007 & 0,323 & 0,052 \\
\hline Wskaźnik stabilności bezrobocia & 0,494 & 0,077 & 0,165 & 0,414 & 0,805 & 0,319 & 0,478 & 0,602 \\
\hline Średni wiek bezrobotnych & 0,229 & 0,848 & 0,269 & 0,432 & 0,424 & 0,630 & 0,243 & 0,594 \\
\hline $\begin{array}{l}\text { Udział bezrobotnych } \\
\text { z wykształceniem poniżej zasadniczego }\end{array}$ & 0,463 & 0,077 & 0,540 & 0,308 & 0,749 & 0,207 & 0,208 & 0,124 \\
\hline $\begin{array}{l}\text { Odsetek bezrobotnych przebywających } \\
\text { w tej populacji powyżej } 12 \text { miesięcy }\end{array}$ & 0,117 & 0,434 & 0,652 & 0,328 & 0,343 & 0,758 & 0,211 & 0,513 \\
\hline
\end{tabular}

a Standaryzowany współczynnik BETA interpretujemy jako powiązanie poszczególnych zmiennych niezależnej ze zmienną zależną.

Źródło: Opracowanie własne z wykorzystaniem pakietu komputerowego SPSS. 
Wpływ charakterystyk zatrudnienia na przestrzenne zróżnicowanie decyzji o zawarciu związku małżeńskiego był nieco bardziej zmienny w czasie niż dla bezrobocia.

W roku 1999 na obszarach miejskich jedynie udział osób zatrudnionych w sektorze publicznym determinował przestrzenne zróżnicowanie współczynników małżeńskości, ale zależność ta była ujemna. Charakterystyka ta miała również podobny wpływ na stopień przekształceń wzorca małżeńskości, ale o jego zaawansowaniu decydował też wskaźnik stabilności zatrudnienia. Wbrew oczekiwaniom, w województwach charakteryzujących się relatywnie wysokim udziałem osób pracujących w sektorze publicznym oraz wyższym napływem osób do zatrudnienia niż jego odpływem odnotowujemy niską skłonność do zawierania związku małżeńskiego oraz niski stopień przekształceń wzorca małżeńskości, tj. nie odnotowujemy przesunięcia dominanty rozkładu do starszych grup wieku nowożeńców. W roku 2010 żadna z wymienionych wcześniej charakterystyk nie determinowała regionalnych różnic w małżeńskości. Na znaczeniu zyskał zaś wskaźnik zatrudnienia. Im wyższe były jego wartości, tym wyższa była również skłonność do zawarcia związku małżeńskiego według województw. Można zatem przypuszczać, że wzrost gwarancji zatrudnienia sprzyjał decyzji o zawarciu związku małżeńskiego, niezależnie od wieku nowożeńców.

Tabela 5. Parametry liniowej regresji wielorakiej współczynnika małżeńskości oraz wzorca małżeńskości opisywanej przez zmienne zatrudnienia według miejsca zamieszkania w latach 1999 i 2010

\begin{tabular}{|c|c|c|c|c|}
\hline \multirow{4}{*}{ Zmienne niezależne } & \multicolumn{4}{|c|}{$\begin{array}{c}\text { Współczynniki niestandaryzowane } \\
\text { [błąd standardowy] }\end{array}$} \\
\hline & \multicolumn{2}{|c|}{ współczynnik małżeńskości } & \multicolumn{2}{|c|}{ wzorzec małżeńskości } \\
\hline & 1999 & 2010 & 1999 & 2010 \\
\hline & \multicolumn{4}{|c|}{ miasto } \\
\hline Wskaźnik zatrudnienia & $-0,043[0,041]$ & $-0,033[0,046]$ & $-0,003[0,004]$ & $-0,005[0,003]$ \\
\hline $\begin{array}{l}\text { Odsetek osób zatrudnionych } \\
\text { w sektorze publicznym }\end{array}$ & $-0,056[0,022]$ & $-0,015[0,030]$ & $-0,003[0,002]$ & $-0,000[0,002]$ \\
\hline \multirow[t]{2}{*}{$\begin{array}{l}\text { Wskaźnik stabilności } \\
\text { zatrudnienia }\end{array}$} & $+0,005[0,010]$ & $-0,001[0,018]$ & $+0,002[0,001]$ & $-0,001[0,001]$ \\
\hline & \multicolumn{4}{|c|}{ wieś } \\
\hline Wskaźnik zatrudnienia & $-0,099[0,081]$ & $+0,011[0,059]$ & $+0,004[0,005]$ & $+0,002[0,004]$ \\
\hline $\begin{array}{l}\text { Odsetek osób zatrudnionych } \\
\text { w sektorze publicznym }\end{array}$ & $-0,061[0,043]$ & $-0,047[0,038]$ & $-0,005[0,003]$ & $-0,002[0,002]$ \\
\hline $\begin{array}{l}\text { Wskaźnik stabilności } \\
\text { zatrudnienia }\end{array}$ & $+0,041[0,020]$ & $-0,029[0,023]$ & $-0,001[0,001]$ & $+0,001[0,001]$ \\
\hline
\end{tabular}

Źródło: Opracowanie własne z wykorzystaniem pakietu komputerowego SPSS. 
Na obszarach wiejskich w roku 1999 wszystkie z wyróżnionych zmiennych zatrudnienia istotnie określały poziom natężenia małżeńskości. W województwach charakteryzujących się wysokim wskaźnikiem zatrudnienia oraz wysokim udziałem osób zatrudnionych w sektorze publicznym odnotowujemy niską skłonność do zawarcia związku małżeńskiego. Natomiast dla wskaźnika stabilności zatrudnienia sytuacja była odwrotna. W przypadku tej ostatniej charakterystyki odnotowujemy również ujemne skorelowanie ze wzorcem. W roku 2010 zmienne te nie wpływały już istotnie na przestrzenne zróżnicowanie tego procesu. Podobnie jak dla obszarów miejskich, wbrew przewidywaniom, ani stabilność zatrudnienia, ani praca w sektorze publicznym nie skłaniały do zawierania związków małżeńskich w ujęciu przestrzennym.

Tabela 6. Siła zależności między zmiennymi wykorzystanymi w modelu liniowej regresji wielorakiej współczynnika małżeńskości oraz wzorca małżeńskości opisywanymi przez zmienne zatrudnienia według miejsca zamieszkania w latach 1999 i 2010

\begin{tabular}{|c|c|c|c|c|c|c|c|c|}
\hline \multirow{4}{*}{ Zmienne niezależne } & \multicolumn{4}{|c|}{$\begin{array}{c}\text { Współczynniki standaryzowane } \\
\text { BETA }\end{array}$} & \multicolumn{4}{|c|}{$\begin{array}{c}\text { Współczynniki standaryzowane } \\
\text { BETA }^{\mathrm{a}}\end{array}$} \\
\hline & 1999 & 2010 & 1999 & 2010 & 1999 & 2010 & 1999 & 2010 \\
\hline & \multicolumn{2}{|c|}{ miasto } & \multicolumn{2}{|c|}{ wieś } & \multicolumn{2}{|c|}{ miasto } & \multicolumn{2}{|c|}{ wieś } \\
\hline & \multicolumn{4}{|c|}{ współczynnik małżeńskości } & \multicolumn{4}{|c|}{ wzorzec małżeńskości } \\
\hline Wskaźnik zatrudnienia & 0,342 & 0,229 & 0,407 & 0,052 & 0,285 & 0,537 & 0,179 & 0,254 \\
\hline $\begin{array}{l}\text { Odsetek osób zatrudnionych } \\
\text { w sektorze publicznym }\end{array}$ & 0,744 & 0,157 & 0,420 & 0,345 & 0,480 & 0,062 & 0,288 & 0,493 \\
\hline Wskaźnik stabilności zatrudnienia & 0,142 & 0,011 & 0,583 & 0,307 & 0,443 & 0,142 & 0,249 & 0,058 \\
\hline
\end{tabular}

a Standaryzowany współczynnik BETA interpretujemy jako powiązanie poszczególnych zmiennych niezależnej ze zmienną zależną.

Źródło: Opracowanie własne z wykorzystaniem pakietu komputerowego SPSS.

Analiza przestrzennego zróżnicowania procesu zawierania małżeństw w powiązaniu ze zmiennymi opisującymi różne aspekty rynku pracy wykazała, że wpływ tych charakterystyk nie był jednoznaczny oraz zmieniał się w czasie. Ponadto tylko nieznacznie różnicował zachowania matrymonialne na obszarach miejskich i wiejskich. 


\section{Wnioski końcowe}

W ostatniej dekadzie proces zawierania małżeństw w ujęciu ogólnopolskim podlegał nielicznym, ale wyraźnym wahaniom w czasie. Podobne tendencje wystąpiły również w województwach, ale natężenie tych zmian znacznie je różnicowało oraz odmiennie kształtowało się na obszarach miejskich i wiejskich. Spowodowało to, że z czasem regionalne różnice w natężeniu zawierania małżeństw według miejsca zamieszkania nowożeńców nieco się zmniejszyły. Jednocześnie trudno jest wyodrębnić zwarte przestrzennie obszary Polski, które charakteryzują się podobnym natężeniem tej miary.

Z czasem w ujęciu ogólnopolskim rozkład cząstkowych współczynników zawierania małżeństw według wieku nowożeńców uległ zmianie. Stał się on nieco bardziej spłaszczony, a dominanta rozkładu przesunęła się z grupy wieku 20-24 lata do grupy 25-29 lat. Jednocześnie nie we wszystkich obiektach odnotowujemy podobne zmiany, a ich natężenie zależało od miejsca zamieszkania nowożeńców. Ponadto województwa charakteryzujące się podobnym wzorcem małżeńskości nie tworzyły zwartych przestrzennie obszarów. Rozrzucone były po całym obszarze Polski, tworząc jednolub wieloelementowe skupiska.

Zastosowany model regresji wielorakiej wskazuje na istotny wpływ rynku pracy na regionalne zróżnicowanie procesu zawierania małżeństw, ale nie dla każdej zmiennej go opisującej był on istotny. Dodatkowo ocena ich wpływu zależała od okresu badania i miejsca zamieszkania nowożeńców.

Na początku badanego okresu na obszarach miejskich w województwach, gdzie szanse zostania osobą bezrobotną było relatywnie większe niż w innych obiektach, odnotowujemy niskie natężenie współczynników małżeńskości oraz mniej zaawansowane przekształcenia wzorca małżeńskości. Na obszarach tych decyzje o zawarciu związku nie były zatem odkładane do starszych grup wieku nowożeńców. Ponadto zła sytuacja na regionalnym rynku pracy dla osób bezrobotnych charakteryzujących się niskim kapitałem ludzkim nie była czynnikiem ograniczającym decyzję o zawarciu związku małżeńskiego, ale jedynie wpływała na jej podjęcie w nieco starszym wieku. Wśród zmiennych zatrudnienia jedynie udział osób pracujących w sektorze publicznym oraz wskaźnik stabilności zatrudnienia wpływał na przestrzenne zróżnicowanie tego procesu. Jednocześnie charakterystyki te wpływały destymulująco na skłonność do zawierania związku małżeńskiego oraz stopień przekształceń wzorca małżeńskości.

Dekadę później już nieco inne czynniki wpływały na przestrzenne zróżnicowanie małżeńskości. W województwach, gdzie odnotowaliśmy wysoką skłonność do 
małżeńskości, osoby bezrobotne charakteryzowały się relatywnie młodą strukturą wieku oraz wysokim udziałem osób bezrobotnych przebywających w tej populacji powyżej dwanaście miesięcy. Natomiast wskaźnik zatrudnienia wskazuje, że im wyższe jego wartości, tym wyższa również ta skłonność. Obserwacje te wskazują, że $\mathrm{z}$ jednej strony sytuacja na regionalnym rynku pracy przestała mieć znaczenie przy podejmowaniu decyzji o zawarciu związku małżeńskiego oraz nie powodowała odraczania jego zawarciu do starszych grup wieku nowożeńców, z drugiej zaś gwarancja zatrudnienia nieco je przyspieszała.

Na obszarach wiejskich sytuacja wyglądała nieco inaczej. Wprawdzie w roku 1999 również i tu istotne znaczenie dla przestrzennego zróżnicowania małżeńskości miało wykształcenie bezrobotnych, ale na znaczeniu zyskał również okres przebywania w populacji bezrobotnych. Jednocześnie pierwsza $\mathrm{z}$ tych charakterystyk działała stymulująco dla procesu zawierania małżeństw, a druga ograniczająco. Równocześnie zła sytuacja na rynku pracy wpływała na stopień przekształceń wzorca małżeńskości. W województwach, gdzie napływ do bezrobocia przewyższał jego odpływ, decyzje o zawarciu związku podejmowane były przez osoby stosunkowo młode. Można zatem przypuszczać, że różny stopień zagrożenia bezrobociem na wojewódzkich rynkach pracy istotnie nie ograniczał przestrzennej skłonności do zawarcia związku małżeńskiego. Natomiast w województwach, gdzie odnotowaliśmy relatywnie wysoki wskaźnik zatrudnienia oraz wysoki udział osób zatrudnionych w sektorze publicznym, wystąpiła niska skłonność do małżeńskości oraz niskie przekształcenia tego wzorca.

Dziesięć lat później sytuacja wyglądała nieco inaczej. Zła sytuacja na regionalnych rynkach pracy ograniczała decyzje o zawarciu związku małżeńskiego, a jeżeli już były one podejmowane, to przez osoby stosunkowo młode. Natomiast zmienne zatrudnienia nie wpływały na to zróżnicowanie.

\section{Employment instability and marriage in rural and urban areas of Poland during last decade}

The article is devoted to the analysis of marriage by regions according to the rate of marriage and the pattern of marriage. The goal is to find similar regions. One of many determinants of diversity between the regions in marriage patterns is the situation on labour market. Using a linear regression model we can observe together these regional processes and describe main characteristics of unemployment and employment which substantially contribute to regional diversification of marriage. 


\section{L'instabilité de l'emploi et les comportements matrimoniaux dans les zones urbaines et rurales en Pologne durant la dernière décennie}

Larticle est consacré à l'analyse des comportements matrimoniaux selon la voïvodie, qui sont décrits par le taux de nuptialité et le modèle de mariage. Lobjectif est d'identifier les régions similaires en raison du phénomène examiné. L'un des nombreux déterminants, qui influent sur les différences spatiales dans les comportements matrimoniaux, est la situation sur le marché du travail. Lauteur analyse la coexistence de ces processus au niveau régional à l'aide du modèle de régression linéaire multiple. L’article indique les caractéristiques de l’emploi et du chômage, qui contribuent de manière significative à la variation de l'intensité des selon la voïvodie. 